\title{
Prematüre Bebeklerde Parenteral Beslenme Komplikasyonları
}

\author{
Kader UZUN* \\ İstanbul Sabahattin Zaim Üniversitesi, Sağllk Bilimleri Fakültesi, Beslenme ve Diyetetik Bölümü, İstanbul, Türkiye \\ İstanbul Sabahattin Zaim Üniversitesi Fen Bilimleri Enstitüsü Dergisi (2022) 4 (1): 18-21 \\ https://doi.org/10.47769/izufbed.1057745 \\ (iD) ORCID 0000-0000-0000-0000
}

\begin{tabular}{l}
\hline YAYIN BİLGİSI \\
\hline Yayın geçmişi: \\
Gönderilen tarih: 14 Ocak 2022 \\
Kabul tarihi:16 Şubat 2022 \\
\hline Anahtar kelimeler: \\
Prematüre \\
Parenteral beslenme \\
Komplikasyon
\end{tabular}

ÖZET

Total Parenteral Beslenme (TPN) oral veya enteral yoldan beslenemeyen hastalara uygulanmaktadır. Parenteral beslenmenin en yaygın kullanıldı ğ bebek grubu prematüre bebeklerdir. Parenteral beslenmenin bebeklerde ilk başarılı uygulamaları 1960'lı yıllarda yapılmıştır. Prematüre bebeklerde parenteral beslenme gereksinim duyulan karbonhidrat, protein, yağ, vitamin ve mineralleri karşılamalıdır. Bu grup bebeklerde doğumdan sonra glikoz, ilk 12 saat içinde aminoasit, 24-48 saat içinde lipid solüsyonu başlanmalıdır. TPN uygulanan prematüre bebeklerde birçok komplikasyonlar görülebilmektedir. Bu çalışmanın amacı, prematürelerde total parenteral beslenme gereksinimleri ve uygulanan bu beslenme şeklinin yol açtığı komplikasyonların geniş çaplı incelenmesidir.

\section{Parenteral Nutritional Complications in Premature Babies}

\begin{tabular}{l}
\hline ARTICLE INFO \\
\hline Article history: \\
Received: 14 January 2022 \\
Accepted: 16 February 2022 \\
\hline Key words: \\
Premature \\
Parenteral nutrition \\
Complication
\end{tabular}

\section{Giriş}

Dünya Sağlık Örgütü tarafindan 1948 'de prematürenin tanımı 2500 g'ın altında veya henüz 38. haftasını doldurmamış bebekler için kullanılmıştır (Arslan, 2013). Total parenteral beslenme (TPN) oral veya enteral yoldan beslenmenin karşılanamaması durumunda beslenmenin intravenöz (IV) olarak yapılmasıdır. Parenteral beslenme ilk olarak bir köpek yavrusunun besin ihtiyaçlarının parenteral beslenme yolu ile karşılanması sonucunda ortaya çıkmıştır (Yiğit, Oğuz ve Dilmen, 2015). Bir bebekte uygulanması ise ilk defa 1944 yılında gerçekleşmiştir. Ancak uygulamalar 1960'lı yıllarda başarıya ulaşmıştır (Aydıner ve İnan, 2004). İlerleyen yıllarda yapılan çalışmalarla birlikte daha uygun venöz yolların bulunması, yağ preparatlarının geliştirilmesi, gerekli vitamin ve minerallerin venöz olarak sağlanması ve kristalize aminoasit solüsyonlarının hazırlanması sonucunda parenteral beslenme yaygınlaşmış ve klinik kullanımı artmıştır (Yiğit ve ark., 2015).
Parenteral beslenmenin " son 20 yılın tedavi alanındaki en anlamlı ilerlemesi" olarak nitelendirilmesinde başarılı klinik bulgular etkili olmuştur (Köksal ve Özel, 2019).

Parenteral beslenme santral ven veya periferik ven yoluyla uygulanır. Uygulanacak solüsyon ozmolaritesi $800 \mathrm{mOsm} / \mathrm{L}$ üzerinde ise santral ven yoluyla verilmelidir (Kendirli, 2011). Parenteral beslenmenin en yaygın uygulandığı bebek grubu prematüre bebeklerdir. Özellikle 1000 g'in altındaki bebeklerde doğumdan itibaren uzun dönem parenteral beslenme uygulanmasına ihtiyaç duyulabilir. (Köksal ve Özel, 2019). Düşük doğum ağırlıklı prematüre bebeklerde doğumdan hemen sonra intravenöz olarak glikoz solüsyonun başlanması, ilk 12 saat içerisinde aminoasitlere başlanması ve 24-48 saatte lipid solüsyonunun başlanması gerekmektedir. Total parenteral beslenme solüsyonları sıvı, enerji, karbonhidrat, protein, lipid, vitamin ve mineralleri içermektedir (Gürsoy ve Yurdakök, 2008).

\section{Prematürelerde Parenteral Beslenme}

*E-mail adresi: kaderuzun.14@hotmail.com (Kader UZUN) 


\section{Gereksinimleri}

Doğru beslenme müdahalesini uygulamak için yenidoğan birimlerinin Amerikan Parenteral ve Enteral Beslenme Derneği (ASPEN), Avrupa Klinik Beslenme ve Metabolizma Derneği (ESPEN) ve İspanyol Klinik Beslenme ve Metabolizma Derneği (SENPE) tarafindan oluşturulan kılavuzların incelenmesi gerekmektedir (Sánchez-García, Zaragoza-Martí, Murcia-López, Navarro-Ruiz, \& Noreña-Peña, 2020).

\subsection{Karbonhidratlar}

Glikoz yeni doğan bebekte temel enerji kaynağıdır. Glikozun depolanması 6. aydan itibaren başladığı için prematüre bebeklerde glikoz çok kısıtlıdır. Bu yüzden prematüre bebeklere doğumdan itibaren glikoz solüsyonu başlanmalıdır (Arslan, 2013). Parenteral beslenmede uygulanan glikoz çeşidi dekstroz (D-glikoz) dur (Kendirli, 2011). Türk Neonatoloji Derneği'ne göre prematüre bebeklerde parenteral glikoz alımı ilk gün 7-10 g/kg olmalıdır. 2-7 gün içerisinde ise $8-15 \mathrm{~g} / \mathrm{kg}$ olmalıdır (Kültürsay, Bilgen ve Türkyılmaz, 2018).

\subsection{Protein}

Prematüre bebeklerde protein gereksinimi $2.5-3 \mathrm{~g} / \mathrm{kg} / \mathrm{gün}$ dır (Çıtak ve Uzel, 2006). Protein gereksinimi parenteral beslenmede aminoasit solüsyonlarıyla karşılanmaktadır (Bozkurt, 2010). Türk Neonatoloji Derneği'ne göre prematürelerde parenteral protein alımı ilk gün $2-3 \mathrm{~g} / \mathrm{kg}$ olmalıdır. $2-7$ gün arasımda $3.5 \mathrm{~g} / \mathrm{kg}$ olmalıdır (Kültürsay ve ark., 2018).

\section{$2.3 \mathrm{Yağ}$}

Ek enerji sağlamak ve esansiyel yağ asidi eksikliğini önlemek için parenteral yolla lipid solüsyonları verilmektedir (Çavuşoğlu, 2001). TPN'de kullanılan lipid emülsiyonları fosfolipid ve trigliseritlerden oluşmaktadır. Soya yağı bazlı uzun zincirli trigliseritler (LCT), hindistan cevizi yağından orta zincirli trgliseritler (MCT) ve balık yağı içeren karışımlar ticari olarak kullanılan lipid formüllerindendir (Kutlay ve Gündoğdu, 2011). En son çalışmalar vücut ağırlığı $<1500$ g olan yenidoğanlarda, ilk günden itibaren $2 \mathrm{~g} / \mathrm{kg} /$ gün lipid alımının güvenli olduğunu ve bebeklerin nitrojen dengesini iyileştirdiğini göstermektedir (Sánchez-García et al., 2020).

\subsection{Enerji}

Prematüre bebeklerin glikojen depolarının ve vücut yağ dokularının az olması dolayısıyla enerji depoları kısıtlıdır (Gülcan, 2010). 1000 $\mathrm{g}$ altındaki prematüre bebekler $90-100 \mathrm{kcal} / \mathrm{kg}$ enerji gerekmektedir. İlk gün için enerji parenteral alım 40-50 kcal/kg önerilmektedir. Bir hafta içinde ise 70-80 kcal/kg önerilmektedir (C.Denne, 2018).

\subsection{Vitamin ve Mineraller}

Vitamin ve mineraller diğer parenteral beslenme solüsyonlarıyla birlikte sağlanmalıdır. Kalsiyum ve fosfor üçüncü trimesterden itibaren depolandığ 1 için prematürelerde yetersizdir. Günde 2-4 $\mathrm{mEq} / \mathrm{kg}$ kalsiyum ve $1-2 \mathrm{mEq} / \mathrm{kg}$ fosfor önerilmektedir (Patel \& Bhatia, 2016). C vitamini $15-25 \mathrm{mg} / \mathrm{kg} / \mathrm{gün}$, A vitamini $700-1500$ $\mathrm{IU} / \mathrm{kg} /$ gün ve $\mathrm{K}$ vitamini $10 \mathrm{mcg} / \mathrm{kg} /$ gün önerilmektedir (Vanek et al., 2012).

\section{Parenteral Beslenme Komplikasyonları}

\subsection{Metabolik komplikasyonlar}

$3.1 .1 \quad$ Karbonhidrat uygulamastyla ilgili
komplikasyonlar

Hiperglisemi görülmesi sonucunda insülin infüzyonu, solüsyon hızının azaltılması ve karbonhidrat solüsyonunun yavaş arttırılması kan şekerinin normal sınırlara gelmesini sağlamaktadır (Demirkol, 2011). Prematüre bebeklerde, sınırlı glikojen rezervleri nedeniyle hipoglisemi görülebilmektedir (Brine, E., \& Ernst, J. A., 2004). Hipoglisemi, aniden kesilen parenteral beslenme sonucunda görülebilmektedir. Bu yüzden infüzyon aşamalı olarak azaltılmalıdır (Aydıner ve İnan, 2004).

\subsubsection{Protein uygulamasıyla ilgili komplikasyonlar}

Aminoasit konsantrasyonun yüksek olması protein sentezini arttırarak fosfat ve potasyumun düşmesine neden olmaktadır (Özkan, Başak, Köksal, Dorum ve Çakır, 2019). Azotermi görüldüğünde infüzyon hızı azaltılmalıdır. Böbrek fonksiyonları ve hipohidrasyon durumu kontrol edilmelidir (Sobotka \& Camilo, 2009).

\subsubsection{Lipid uygulamastyla ilgili komplikasyonlar}

Hipertrigliseridemi (HiTG) TPN alan bebeklerde s1k görülen metabolik bir komplikasyondur. Sınırlı kas ve yağ kütleleri nedeniyle lipoprotein lipaz enziminin hidrolitik kapasitesi azalan prematüre bebekler term bebeklere göre HiTG açısından risk altındadır (Correani et al., 2019).

TPN uygulanan lipid solüsyonlarının sonucunda görülen kolestaz ciddi bir komplikasyondur. Yapılan bir çalışmaya göre 2-4 hafta parenteral beslenme uygulanan bebeklerde \%18-67 oranında kolestaz gözlenmiştir (Özkan ve diğer., 2019). Yüksek dozda lipid başlanması ve hızlı arttırılması kolestaz oluşumunu arttırmaktadır (Kültürsay ve ark., 2018). TPN ile ilişkili kolestazlı (PNAC) bebeklerde, parenteral bakır takviyesi, bakır atılımı sonucu biliyer atılımın azalmasından dolayı hepatik bakır birikimi nedeniyle hepatoselüler hasar görülebilmektedir. $\mathrm{Bu}$ nedenle, PNAC'l bebeklerde günlük parenteral bakır desteği rutin olarak kullanılmamaktadır (Gupta, K., Wang, H., \& Amin, S. B., 2018). Kolestaz tedavisinde ursodeoksikolik asit kullanımı sonucunda ursodeoksikolik asitin kolestaz süresini kısalttı̆g 1 gözlemlenmiştir (Çetin ve diğer., 2006).

\subsubsection{Eser element yetersizlikleri}

Eser element eklenmeyen parenteral beslenmede çinko eksikliğine rastlanmaktadır (Aydıner ve İnan, 2004). Prematüre bebeklerde görülen bakır eksikliği sonucunda osteopeni görülmektedir. Ancak günümüzde parenteral beslenmenin mineraller ile verilmesi sonucunda görülme sıklığı azalmaktadır (İpek, Çekmez ve Berber, 2015).

\subsubsection{Elektrolit bozuklukları}

Son çalışmalar aminoasit ve lipid solüsyonlarının erken başlanmasının hipokalemi ve hipofosfatemi oluşumunu arttırdığını göstermektedir. Özellikle aşırı düşük doğum ağırlıklı bebeklerde uygulanan aminoasit solüsyonlarıyla hipofosfateminin ilişkili olduğu görülmüştür (Özkan ve diğer., 2019). Yapılan bir çalışmaya göre en az 24 saat total parenteral beslenen 294 prematüre bebeğin 19'unda hipokalsemi, hipopotasemi ve hiponatremi gibi elektrolit bozuklukları gözlenmiştir (Köşger, Özer ve Helvacı, 2016).

\subsection{Mekanik komplikasyonlar}

TPN periferik veya santral vene katater takılarak uygulanmaktadır (Aydıner ve İnan, 2004). Katatere ilişkin yaygın enfeksiyonlar oluşmaktadır. En fazla görüleni katater çevresindeki deri ve deri altında oluşan enfeksiyonlardır. Deriden sürüntü alınarak teşhis edilmeli ve antibiyotiğe başlanmalıdır (Hill, Ksiazyk, Prell, \& 
Tabbers, 2018). TPN'de sık görülen diğer enfeksiyon ise katatere bağlı kan dolaşımı enfeksiyonudur. Enfeksiyon riski personelin el hijyenine önem vermesi ve ultrasyonla kataterin yerleştirmesi sonucu azaltılabilir (Kutlay ve Gündoğdu, 2011). Santral vene katater takilırken hava embolisi, pnömotoraks, hemotoraks ve pleksus brakialis zedelenmesi görülebilmektedir (Azizi, 2017). Kataterin çıkarılmasından 24 saat sonra ve takılmasından 48 saaat sonra enfeksiyon gözleniyorsa bu enfeksiyon başka bir nedenden kaynaklanmiyorsa enfeksiyonun nedeninin kataterle ilgili olduğu düşünülmektedir. Enfeksiyon oluşumunu engellemek için katater yeri steril tutulmalıdır. Katater yeri alkol ile temizlenmeli ve günlük bakımı yapılmalıdır (Satar, Arısoy ve Çelik, 2018).

\subsection{Septik komplikasyonlar}

TPN uygulanmasından sonra sık görülen komplikasyonlardan biri sepsistir. Bununla birlikte safra stazıda sepsis hızında artışa neden olabilmektedir. Sepsis sırasında AST, ALT gibi karaciğer enzimlerinde artış gözlenebilmektedir. Sepsis sonucunda ise kolestaz görülebilmektedir. (Btaiche \& Khalidi, 2002). TPN uygulanmasına bağlı olarak karaciğerde görülen hasar kolestaz olarak adlandırılmaktadır (Fu, 2019). Kolestaz gelişiminde TPN lipid solüsyonları önemli bir role sahiptir (Özkan ve diğer., 2019). Uzun süreli TPN gerektiren hastalarda lipid uygulamasını değiştirerek kolestazı önleme veya tersine çevirme üzerine çalışmalar yapılmıştır. Bu çalışmalar arasında lipid minimizasyonu, geçici süre lipidlerin kesilmesi ve lipid kaynaklarının soya fasulyesi yağı dışındaki lipid solüsyonlarından kullanılması yer almaktadır (Goulet, Cai \& Seo, 2020).

\section{Sonuç}

Yapılan çalışmalar parenteral beslenmenin prematüre bebeklerde ne denli önemli ve hayati olduğunu gösteriyor. Parenteral beslenmeye ihtiyaç duyan hasta grubuna beklemeksizin başlanmalıdır. Yapılan çalışmalarda görülen komplikasyonlar gösteriyor ki parenteral beslenme solüsyon hızının arttılması veya azaltılması, tamamen kesilmesi, vitamin ve minerallerin yetersiz verilmesi, katater bakımının titizlikle yapılmaması parenteral beslenmeden alınan verimi düşürmektedir. $\mathrm{Bu}$ nedenle parenteral beslenme uygulamalarının takibinin iyi yapılması gerekmektedir.

\section{Kaynaklar}

Arslan, M. (2013). Prematüre Bebeklerde Total Parenteral Beslenmeden Tam Enteral Beslenmeye

Farklı Geçiş Yöntemlerinin Klinik Sonuçlara Etkileri (Yayımlanmış yüksek lisans tezi). Dokuz Eylül Üniversitesi, İzmir.

Aydıner, Ç. ve İnan, M. (2004). Çocuk cerrahisinde total parenteral beslenmenin yol açtığı sorunlar. Trakya Üniversitesi Tip Fakültesi Dergisi, 21(1-3), 11-16.

Azizi, A. (2017). Güncel Parenteral Beslenme Tedavisi Uygulanan Hastaların Değerlendirilmesi, Kateterle İlişkili Gelişen Komplikasyonların Siklıkları Ve Özellikleri (Yayımlanmış doktora tezi). İstanbul Üniversitesi, İstanbul.

Brine, E., \& Ernst, J. A. (2004). Total parenteral nutrition for premature infants. Newborn and Infant Nursing Reviews, 4(3), 133-155. doi:10.1053/j.nainr.2004.03.006

Bozkurt, G. (2010). Yoğun bakımdaki çocuğun beslenmesi. Yoğun Bakım Hemşireliği Dergisi, 14(2), 72-78.

C.Denne, S. (2018). Parenteral Nutrition for the High-Risk Neonate. A. Gleason, C. \& E.Juul, S. (Ed.). Avery's diseases of the newborn (10 ${ }^{\text {th }}$ ed.) (1023-1031). Elsevier.

Correani, A., Giretti, I., Antognoli, L., Monachesi, C., Cogo, P., D’Ascenzo, R., Biagetti, C., Carnielli, V. P. (2019). Hypertriglyceridemia and Intravenous Lipid
Titration During Routine Parenteral Nutrition in Small Preterm Infants. Journal of Pediatric Gastroenterology and Nutrition, 69(5), 619-

625. doi:10.1097/mpg.0000000000002459

Çavuşoğlu, H. (2001). Yenidoğan bebeklerde parenteral beslenme ve hemşirelik bakımı. C.Ü. Hemşirelik Yüksekokulu Dergisi, 5(2), 1-8.

Çetin, H., K.Akdeniz, S., Olgar, Ş., Öktem, F., Dündar, B., ve Ayata, A. (2006). Çok düşük doğum ağırlıklı bebeklerde total parenteral beslenme ilişkili kolestaz ve ursodeoksikolik asit tedavisinin etkinliği. S.D. U. Tlp Fakültesi Dergisi, 13(4), 7-11.

Çıtak, A. ve Uzel, N. (2006). Çocuk yoğun bakımda total parenteral beslenme. Yoğun Bakım Derneği Dergisi, 4(1), 32-39.

Demirkıran, O. (2011). ESPEN Parenteral Nutrisyon Rehberleri: Yoğun Bakım. O. Kutlay, ve H. Gündoğdu, (Ed.), ESPEN Parenteral Nutrisyon Rehberi. (1.bask1) 38-52.

Demirkol, D. (2011). Kritik hasta çocuklarda parenteral beslenme. Klinik Gelişim, 24, 44-49.

F.Btaiche, I., \& Khalidi, N. (2002). Parenteral nutrition-associated liver complications in children. Pharmacotherapy, 22(2), 188-211.

Fu, R.H. (2019). Selection of lipid emulsions for protection against parenteral nutrition-associated

liver disease. Pediatrics and Neonatology, 60, 355-356. doi:10.1016/j.pedneo.2019.06.008

Gupta, K., Wang, H., \& Amin, S. B. (2018). Copper Supplementation in Premature Infants With Parenteral Nutrition-Associated Cholestasis. Nutrition in Clinical Practice. doi:10.1002/ncp.10053

Gülcan, H. (2010). Preterm yenidoğanlarda parenteral beslenmede yenilikler. Gaziantep Tip Dergisi, 16(2), 66-74.

Gürsoy, T ve Yurdakök, M. (2008). Prematüre bebeklerin beslenmesi. Çocuk Să̆lı̆̆ ve Hastalıkları Dergisi, 51, 240-251

Goulet, O. J., Cai, W., \& Seo, J. (2020). Lipid emulsion use in pediatric patients requiring long-term parenteral nutrition. Journal of Parenteral and Enteral Nutrition, 44(1), 55-67. doi:10.1002/jpen.1762

Hill, S., Ksiazyk, J., Prell, C., \& Tabbers, M. (2018). ESPGHAN/ESPEN/ESPR/CSPEN guidelines on pediatric parenteral nutrition: Home parenteral nutrition. Clinical Nutrition, 37, 2401-2408. doi:10.1016/j.clnu.2018.06.954

İpek, M., Çekmez, F., ve Berber, M. (2015). Prematüre osteopenisi. Medeniyet Medical Journal, 30(1), 41-50.

Kendirli, T. (2011). Kritik çocuk hastada beslenme. Klinik gelişim, 24, 34-43.

Köksal, G. ve Özel, H. (2019). Prematüre bebeklerde beslenme. Çocuk hastalıklarında beslenme tedavisi (7. Baskı) içinde (175-195). Ankara: Hatiboğlu Yayınevi.

Köşger, P., Özer, E., ve Helvac1, M. (2016). Preterm bebeklerde total parenteral beslenme ile ilişkili komplikasyonların sıklığ ve risk faktörleri. J Pediatr Res, 3(3), 149-153.

Kültürsay, N., Bilgen, H. ve Türkyılmaz, C. (2018). Türk Neonatoloji Derneği Prematüre ve Hasta Term Bebeğin Beslenmesi Rehberi. 6-19.

Özen, H. (2011). ESPEN Parenteral Nutrisyon Rehberleri: Santral Venöz Kataterler. O. Kutlay, ve H. Gündoğdu, (Ed.), ESPEN Parenteral Nutrisyon Rehberi. (1.bask1) 12-26.

Özkan, H., Başak, M.F., Köksal, N., Dorum, B. ve Çakır, S.Ç. (2019). Prematüre bebeklerde erken agresif total parenteral nütrisyonun biyokimyasal parametreler üzerine etkileri. Güncel Pediatri, 17(3), 337-349.

Özkan, H., Köksal, N., Doğan, P., G.Varal, İ., Bağc1, O., ve Özgür, T. (2019). The effectiveness of serum amyloid A for prediction of neonatal cholestasis associated with parenteral nutrition in premature infants. The Turkish Journal of Pediatrics, 61, 26-33. 
Patel, P. \& Patia, J. (2016). Total parenteral nutrition for the very low birth weight infant. Seminars in Fetal \& Neonatal Medicine, 1-6. doi: 10.1016/j.siny.2016.08.002

Sánchez-García, A. M., Zaragoza-Martí, A., Murcia-López, A. C., Navarro-Ruiz, A., \& Noreña-Peña, A. (2020). Adequacy of Parenteral Nutrition in Preterm Infants According to Current Recommendations: A Study in A Spanish Hospital. International Journal of Environmental Research and Public Health, 17(6),

2131. doi:10.3390/ijerph17062131

Satar, M., Arısoy, A., ve Çelik, İ.H. (2018). Türk Neonatoloji Derneği Yenidoğan Enfeksiyonları Tanı ve Tedavi Rehberi. 6-21.

Sobotka, L. \& Camilo, M.E. (2009). Basics in clinical nutrition: metabolic complications of parenteral nutrition. e-SPEN, the European e-Journal of Clinical Nutrition and Metabolism, 4, 120-122.

Vanek, V.W., Borum, P., Buchman, A., Fessler, T.A., Howard, L., Jeejeebhoy, K., Kochevar, P., Shenkin, A. \& Valentine, C.J. (2012). Recommendations for changes in commercially available parenteral multivitamin and multi-trace element products. Nutrition in Clinical Practice, 27(4), 440-491. doi: $10.1177 / 0884533612446706$

Yiğit, A., Oğuz, Ş. ve Dilmen U. (2015). Parenteral beslenen prematüre bebeklerde alüminyum düzeyleri. Jinekoloji Obstetrik ve Neonatoloji Tip Dergisi, 11(3), 126-129. 